\title{
THE SENSITIVITY OF DIFFERENT GROWTH STAGES OF SUNFLOWER (HELIANTHUS ANNUUS L.) UNDER DEFICIT IRRIGATION
}

\author{
MAHMOOD, H. N. ${ }^{*}-$ TOWFIQ, S. I. ${ }^{1}-$ RASHID, K. A. $^{2}$ \\ ${ }^{1}$ Crop Science Department, College of Agricultural Sciences, University of Sulaimani, \\ Sulaimani-Kurdistan Region, Iraq \\ ${ }^{2}$ Soil and Water Science Department, College of Agricultural Sciences, University of Sulaimani, \\ Sulaimani-Kurdistan Region, Iraq \\ *Corresponding author \\ e-mail: hekmat.mahmood@univsul.edu.iq; phone: +964-750-126-9838
}

(Received $8^{\text {th }}$ Mar 2019; accepted $3^{\text {rd }}$ May 2019)

\begin{abstract}
Sunflower-like all other plants have several growth stages such as vegetative, flowering, and achene formation. Water stress mainly results in a reduction in seed yield during the flowering more than the achene formation stage. A randomized complete block design was applied with irrigation as main plots (skipping irrigation at stages of vegetation, flowering, achene formation, and full irrigation), and sunflower genotypes (Barolo RO, Velko, and Local) as sub-plots. Each treatment replicated three times. This study was conducted at two different locations (Kanipanka and Qlyasan) under the semiarid region of Sulaimani province, Iraq. Velko genotype had the highest seed yield of 4,993.705, and $6,247.265 \mathrm{~kg} \mathrm{ha}^{-1}$ respectively at both locations, under full irrigation. Under skipping irrigation, at both stages of flowering and achene formation, irrigation water use efficiency value was lower than the value of water use efficiency. Crop response factor was less than one for all genotypes. At the flowering stage and under skipping irrigation, the crop response factor was higher at both locations. The result of this study concluded that Barolo RO genotype has the highest performance under deficit irrigation. Also, under skipped irrigation, the flowering stage was more effective in seed yield increase than stages of vegetation and achene formation in sunflower. The objective of this study was to determine the sensitivity of sunflower growth stages under deficit irrigation.
\end{abstract}

Keywords: irrigation requirement, saving water, seed yield, water use efficiency, yield response factor

\section{Introduction}

Sunflower (Helianthus annuus L.) is considered one of the top four edible vegetable oils in the world. Globally, it is counted for about $12 \%$ of the edible vegetable oil production following palm, soybean, and canola oil (Demir et al., 2006; Rauf et al., 2017). It is the most effective unconventional oilseed crops in the world due to its high oil quality, and it is advantages in crop rotation systems, such as high adoption capability, suitability to mechanization and low labor needs (Reddy et al., 2003; Kazemeini et al., 2009).

Agriculture uses the highest amount of freshwater which accounts for $70 \%$, that driven from rivers, lakes, and aquifers up to more than $90 \%$ in some developing countries (WWP, 2017). The IPCC AR5 (2013) stressed low confidence in a globalscale observed trend in drought, owing to lack of direct observations, dependencies of inferred trends on the index choice, as well as difficulties in distinguishing long-term climate change from decadal-scale drought variability.

Ghani et al. (2000) found that irrigation is a substantial factor which directly influences the yield of sunflower. Wise application in time for irrigation in critical 
stages of growth from increased sunflower seeds produces dramatically. Sunflower plants can achieve maximum water productivity under water deficit environment (Ali, 2009). Indeed, flowering and seed filling stages have been reported as the most critical for water stress in sunflower (Iqbal et al., 2005). Shafi et al. (2013) indicated that water stress during the flowering stage causes a considerable reduction in seed yield of sunflower.

The identification of the relationship between water use efficiency and seed yield under deficit irrigation has been a high concern for agricultural research in semi-arid areas (Fan et al., 2005; Sun et al., 2006; Sinaki et al., 2007; Faraji et al., 2009). However, one of the biggest challenges facing agriculture is the development of technological options or to improve the efficiency of agricultural water use (Turner, 2004).

Drought is one of the tops stress abiotic factor which causes low yield especially in arid and semi-arid regions of the world (Tian et al., 2016; Viscardi et al., 2016). Martinek (2008) stated that drought tolerance differs strongly between the growth stages of many crops. Deficit irrigation is known as the application of water at levels below full crop water requirements, and it is one of the new strategies designed to improve water savings in agriculture (Bashir and Mohamed, 2014). The purpose of deficit irrigation is to raise the water use efficiency (WUE) and to obtain the highest yield per unit water (Kirda et al., 2006), further De Pascale et al. (2011) describe the ration of crop yield per unit as water use efficiency in agriculture.

By knowing the value of crop response factor, farmers can get optimum yield without withdrawing irrigation water at that stage if water scarcity persists. Doorenbos and Kassam (1979) found the crop response factor $(k y)$ for some crops. Crop response factor values of more than one indicate more stress, and from this value, the critical stage can be obtained. As reported by Ali (2009), the response factor various by locations, which influence by soil types, weather conditions, seasons and varieties. Therefore, a location-specific response factor should be considered for the efficient management of water. Here sunflower crop was used to estimate crop response factor as it can tolerate low to medium water and salinity stress (Tolga and Lokman, 2003).

The genotype differences may be due to the differences in genetic structure between the sunflower genotype, to the differences in growth characters and the differences in photosynthetic partitioning (Ahmed and Hassanein, 2000; Abou El-Seoud and Wafaa, 2010). Hybrid seed yield is a condition by its capacity to use the environmental variables efficiently in different phenophases (Gonzáles et al., 2013). Thus, the genetic potential of the hybrid sunflower is reduced by the action of the growth factors, either environmental or technological. In addition to high yield sunflower varieties, agronomic practices are essential for maximum seed yield (Beg et al., 2007). Ibrahim (2012) reported that the plant population and varieties could determine seed yield per unit area.

The objective of this study was to highlight the sensitivity of different growth stages of three genotypes of sunflower to different irrigation levels.

\section{Materials and methods}

\section{Study area}

This study was carryout during the summer of 2016 at two locations: first the Agricultural Research Station at Kanipanka, Sulaimani with (Longitude of $045^{\circ} 43^{\prime} 22^{\prime \prime}$ $\mathrm{E}$, altitude of $548 \mathrm{masL}$, and latitude of $\left.35^{\circ} 22^{\prime} 22^{\prime \prime} \mathrm{N}\right)$. The second location was 
Qlyasan, the experimental station of the College of Agricultural Sciences, the University of Sulaimani, (latitude: $35^{\circ} 34^{\prime} 17^{\prime \prime} \mathrm{N}$, Longitude: $045^{\circ} 22^{\prime} 00$ ” E, altitude: 757 masL) "Garmin, GPSmap60 Cx" (Fig. 1).

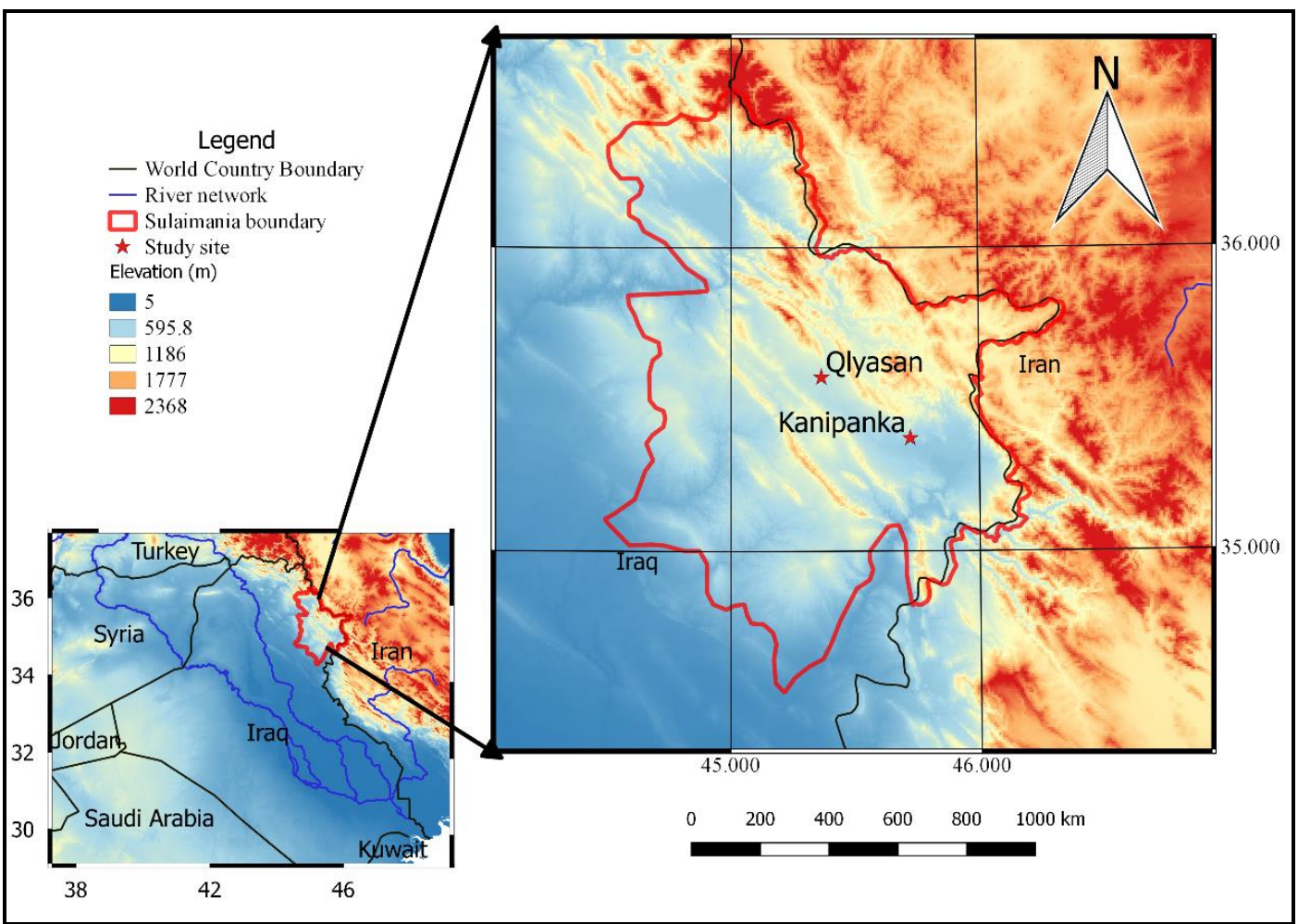

Figure 1. Map of the study site in Sulaimani-Kurdistan region, Iraq

At each location, a composite soil sample of about $5 \mathrm{~kg}$ was obtained by mixing subsamples from 6 sites using a shovel. Each soil sample was freed from plant roots and other debris. All samples were dried at room temperature for seven days. Each sample was cleaned using $2 \mathrm{~mm}$ stainless-steel sieve.

A split-plot factorial with full and deficit irrigation as the main plot was replicated three times, a in randomized complete block design. The water deficit of various degrees was imposed at different growth stages with the irrigation treatments. There were three sunflower growth stages which are vegetative $\left(S_{1}\right)$, flowering $\left(S_{2}\right)$, and achene formation $\left(\mathrm{S}_{3}\right)$ stages. The four levels of irrigation treatments were: skipping irrigation at vegetative stage $\left(\mathrm{I}_{1}\right)$, skipping irrigation at flowering stage $\left(\mathrm{I}_{2}\right)$, skipping irrigation at the achene formation stage $\left(\mathrm{I}_{3}\right)$, and full irrigation $\left(\mathrm{I}_{4}\right)$. Table 1 exhibits the details of the irrigation treatments. Table 2 shows the sum of water applied at different treatments for both locations.

Table 1. Details of the irrigation treatments

\begin{tabular}{c|c}
\hline Irrigation treatments symbol & Description \\
\hline $\mathrm{I}_{1}$ & Skipping irrigation at vegetative stage \\
$\mathrm{I}_{2}$ & Skipping irrigation at flowering stage \\
$\mathrm{I}_{3}$ & Skipping irrigation at the achene formation stage \\
$\mathrm{I}_{4}$ & Full irrigation (non-skipping irrigation) \\
\hline
\end{tabular}


Table 2. Total number of irrigations along with the gross depth of applied water as influenced by different irrigation treatments during the sunflower growing season at the study locations

\begin{tabular}{|c|c|c|c|c|c|}
\hline \multirow{2}{*}{$\begin{array}{l}\text { Irrigation } \\
\text { treatments }\end{array}$} & \multirow{2}{*}{$\begin{array}{l}\text { Number of } \\
\text { irrigations }\end{array}$} & \multicolumn{4}{|c|}{ Total applied water } \\
\hline & & Liters (L) & $(\mathbf{m m})$ & $\left(\mathrm{m} \mathrm{ha}^{-1}\right)$ & $\operatorname{ET}_{a}\left(m^{3} h^{-1}\right)$ \\
\hline \multicolumn{6}{|c|}{ Kanipanka Location } \\
\hline $\mathrm{I}_{1}$ & 11 & 3416 & 632.59 & 6325.93 & 4428.148 \\
\hline $\mathrm{I}_{2}$ & 11 & 3511 & 650.19 & 6501.85 & 4551.296 \\
\hline $\mathrm{I}_{3}$ & 10 & 2872 & 531.85 & 5318.52 & 3722.963 \\
\hline $\mathrm{I}_{4}$ & 18 & 4111 & 761.3 & 7612.96 & 5329.074 \\
\hline \multicolumn{6}{|c|}{ Qlyasan Location } \\
\hline $\mathrm{I}_{1}$ & 10 & 3500 & 648.15 & 6481.48 & 4212.963 \\
\hline $\mathrm{I}_{2}$ & 11 & 3642 & 674.44 & 6744.44 & 4383.889 \\
\hline $\mathrm{I}_{3}$ & 10 & 2669 & 494.26 & 4942.59 & 3212.685 \\
\hline $\mathrm{I}_{4}$ & 18 & 4073 & 754.26 & 7542.59 & 4902.685 \\
\hline
\end{tabular}

The sub-plot factors encompassed of the genotypes which were a single cross hybrid Barolo RO, single cross hybrid Velko and Local variety.

The size of each sub-plots was $3 \mathrm{~m}$ by $1.8 \mathrm{~m}$, and consisted of three rows, with $0.60 \mathrm{~m}$ apart. The spaces between plants were $0.30 \mathrm{~m}$. The least significant difference at confidence levels of 0.05 and 0.01 were used for treatments comparison.

\section{Cultural practices}

Before planting and delineating the plots, an area with a gentle slope was selected an irrigated. The field was then plowed with moldboard plow at the optimum water content for tillage. At both locations, three sunflower seeds at a depth of 2-4 cm were placed in each hole on July 11 and 15, 2016. After two weeks, the seedling was thine out to one per hole. The nitrogen fertilizer in the form of Urea applied one before the second irrigation and the other before flowering at a rate of $43 \mathrm{~kg} \mathrm{ha}^{-1}$ as recommended. Hand weeding practiced as needed. There was not treated with any pesticide. At the flowering stage, plants were protected from bird attack by installing a screen over the heads.

\section{Sulaimani governorate climate}

The climate of Sulaimani governorate is considered as a semi-arid environment: cold and wet in winter, hot and dry in summer. The average temperature from July to August is between $39-43{ }^{\circ} \mathrm{C}$ and often reaching nearly $50{ }^{\circ} \mathrm{C}$. October means high temperatures are $24-29^{\circ} \mathrm{C}$ and slightly cooling down in November. The rainfall is limited to winter and spring months Kurdistan Regional Government, 2018; see Table 3).

\section{Watering schedules}

As recommended by Allen et al. (1988), irrigation scheduling was based on an allowable root zone water depletion of $45 \%(p=0.45)$ during the whole growing cycle. SOTERA digital meter was used to measure the water flow (Fig. 2). 
Table 3. Agrometeorological parameters at Kanipanka and Qlyasan locations 2015-2016

\begin{tabular}{|c|c|c|c|c|c|c|}
\hline \multirow[b]{2}{*}{ Locations } & \multirow[b]{2}{*}{ Month } & \multicolumn{2}{|c|}{ Air temperature ${ }^{\circ} \mathrm{C}$} & \multirow{2}{*}{$\begin{array}{c}\text { Average } \\
\text { humidity } \\
(\%)\end{array}$} & \multirow{2}{*}{$\begin{array}{c}\text { Average } \\
\text { wind speed } \\
\left(\mathrm{ms}^{-1}\right)\end{array}$} & \multirow{2}{*}{$\begin{array}{l}\text { Precipitation } \\
\quad(\mathbf{m m})\end{array}$} \\
\hline & & Minimum & Maximum & & & \\
\hline Kanipanka & $\begin{array}{l}\text { October } \\
\text { November } \\
\text { December } \\
\text { January } \\
\text { February } \\
\text { March } \\
\text { April } \\
\text { May } \\
\text { June } \\
\text { July } \\
\text { August } \\
\text { September } \\
\text { October }\end{array}$ & $\begin{array}{c}10.2 \\
4.5 \\
-2.0 \\
-3.0 \\
0.5 \\
3.2 \\
5.2 \\
12.0 \\
18.7 \\
27.05 \\
29.34 \\
21.42 \\
15.66\end{array}$ & $\begin{array}{l}38.00 \\
21.80 \\
15.90 \\
16.50 \\
22.40 \\
23.00 \\
32.70 \\
40.00 \\
44.80 \\
44.33 \\
45.88 \\
39.55 \\
34.69\end{array}$ & $\begin{array}{l}40.50 \\
51.90 \\
54.40 \\
56.80 \\
49.50 \\
45.90 \\
41.30 \\
31.40 \\
21.70 \\
20.30 \\
19.56 \\
22.68 \\
28.56\end{array}$ & $\begin{array}{l}1.63 \\
1.81 \\
2.23 \\
2.86 \\
2.26 \\
2.33 \\
2.37 \\
2.60 \\
2.68 \\
1.65 \\
1.50 \\
1.61 \\
1.38\end{array}$ & $\begin{array}{c}186.1 \\
143.6 \\
86.1 \\
51.7 \\
87.1 \\
113.5 \\
74.0 \\
10.0 \\
0 \\
0 \\
0 \\
0 \\
0\end{array}$ \\
\hline Qlyasan & $\begin{array}{l}\text { October } \\
\text { November } \\
\text { December } \\
\text { January } \\
\text { February } \\
\text { March } \\
\text { April } \\
\text { May } \\
\text { June } \\
\text { July } \\
\text { August } \\
\text { September } \\
\text { October }\end{array}$ & $\begin{array}{c}22.7 \\
12.0 \\
7.4 \\
5.7 \\
9.8 \\
12.4 \\
17.1 \\
22.4 \\
30.6 \\
25.84 \\
27.49 \\
19.95 \\
14.95\end{array}$ & $\begin{array}{c}25.3 \\
17.6 \\
12.45 \\
10.6 \\
15.7 \\
18.4 \\
23.9 \\
29.8 \\
37.6 \\
43.46 \\
45.36 \\
38.26 \\
32.01\end{array}$ & $\begin{array}{c}42.0 \\
50.6 \\
40.5 \\
40.3 \\
50.0 \\
51.8 \\
43.1 \\
30.2 \\
14.1 \\
22.9 \\
20.35 \\
26.17 \\
29.42\end{array}$ & $\begin{array}{l}1.41 \\
1.54 \\
1.63 \\
1.61 \\
1.67 \\
2.35 \\
1.36 \\
1.40 \\
1.94 \\
1.77 \\
1.60 \\
1.65 \\
1.44\end{array}$ & $\begin{array}{c}96.7 \\
152 \\
52.7 \\
72.5 \\
64.8 \\
122.6 \\
55.2 \\
6.0 \\
0 \\
0 \\
0 \\
0 \\
0\end{array}$ \\
\hline
\end{tabular}

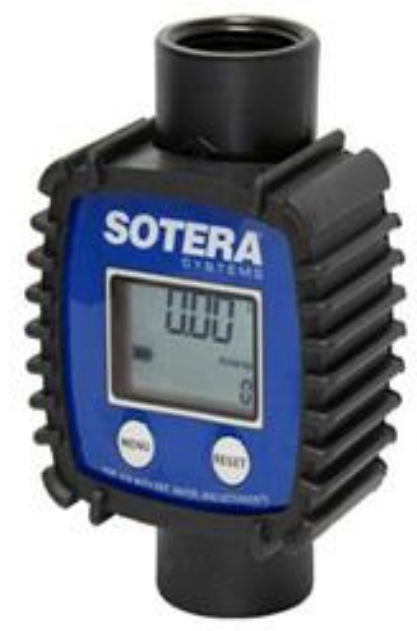

Figure 2. SOTERA digital display meter

A small auger $5 \mathrm{~cm}$ in diameter (Lorenz and Maynard, 1980) was used to observe soil water content. The average water requirement (consumptive crop use) was calculated from soil moisture. The soil moisture was brought to field capacity when the 
available soil moisture was depleted by $45 \%$. The net depth of applied water was calculated from (Michael, 1978):

$$
d_{n}=\frac{\left(\omega_{F C}-\omega_{W P}\right)}{100} \frac{\rho_{b}}{\rho_{w}} P D
$$

where:

$\mathrm{d}_{\mathrm{n}}=$ net depth of applied water $(\mathrm{mm})$

$\omega_{\mathrm{FC}}=$ Soil water retention at $-33 \mathrm{kPa}$

$\omega_{\mathrm{PW}}=$ Soil water retention at $-1500 \mathrm{kPa}$

$\rho_{b}=$ Average soil bulk density of the root zone $\left(\mathrm{gcm}^{-3}\right)$

$\rho_{\mathrm{w}}=$ Water density $\left(\mathrm{gcm}^{-3}\right)$

$\mathrm{P}=$ Depletion fraction $=0.45$

$\mathrm{D}=$ Root zone depth (mm)

The gross depth of applied water (dg) was obtained from the following relationship:

$$
d g=\frac{d_{n}}{E a}
$$

where $\mathrm{Ea}=$ Irrigation application efficiency.

The values of this parameters were 0.70 and 0.65 for Kanipanka and Qlyasan locations, respectively (Table 4).

Table 4. Irrigation application efficiencies for the locations under study based on average land slope and basic infiltration rate

\begin{tabular}{c|c|c|c}
\hline Locations & Average land slope $\mathbf{( \% )}$ & $\begin{array}{c}\text { Basic infiltration rate, } \\
\text { ib }\left(\mathbf{m m ~ h r}^{\mathbf{- 1}}\right)\end{array}$ & $\begin{array}{c}\text { Irrigation application } \\
\text { efficiency, } \mathbf{e}_{\mathbf{a}}\end{array}$ \\
\hline Kanipanka & Nearly level & 44 & 0.70 \\
Qlyasan & 1.16 & 80 & 0.65 \\
\hline
\end{tabular}

The consumptive crop use mean during the growing season was comparable with that computed by the Penman-Monteith equation. In each plot, middle row plants were harvested at maturity for seed yield determination at $10 \%$ seed moisture content. On October 19 and 24, 2016 mature plants were harvested from a deficit and full irrigation plots, respectively, at Kanipanka location, while the harvesting dates at Qlyasan location, was on October 25 for all the irrigation treatments.

The following equation was used to estimate water use efficiency (WUE), and irrigation water use efficiency (IWUE), as the ratio of crop yield per unit of water applied (Kang et al., 2000):

$$
\begin{gathered}
W U E=\frac{Y}{E T_{c}} \\
I W U E=\frac{Y}{I}
\end{gathered}
$$


where:

$\mathrm{Y}=$ The total sunflower seed yield $\left(\mathrm{kg} \mathrm{ha}^{-1}\right)$

$E T_{c}=$ The seasonal evapotranspiration $\left(\mathrm{m}^{3} \mathrm{ha}^{-1}\right)$

$I=$ The total volume of applied irrigation water $\left(\mathrm{m}^{3} \mathrm{ha}^{-1}\right)$

While the irrigation application efficiencies for the locations under study based on average land slop and basic infiltration rate was calculated according to Karim and Karim (2001), and the results are revealed in Table 4.

The crop response factor $k y$ was based on the formula recommended by (Doorenbos and Kassam, 1979).

$$
\left(1-\frac{Y_{a}}{Y_{m}}\right)=k y\left(1-\frac{E T_{a}}{E T_{\max }}\right)
$$

where:

$Y_{a}=$ Actual crop yield $\left(\mathrm{kg} \mathrm{ha}^{-1}\right)$

$Y_{m}=$ Maximum crop yield $\left(\mathrm{kg} \mathrm{ha}^{-1}\right)$

$E T_{a}=$ Actual evapotranspiration (mm)

$E T_{\max }=$ Maximum evapotranspiration $(\mathrm{mm})$

$k y=$ Yield response factor (dimensionless)

The crop response factor for different stages of growth can be described by:

$$
\frac{Y}{Y_{m}}=\Pi_{i=1}^{n}\left[1-K_{y i}\left(1-\frac{E T}{E T_{m}}\right)_{i}\right]
$$

By expanding Equation 4, we find:

$$
\frac{Y}{Y_{m}}=\left[1-k_{y 1}\left(1-\frac{E T_{a}}{E T_{m}}\right)_{1}\right]\left[1-k_{y 2}\left(1-\frac{E T_{a}}{E T_{m}}\right)_{2}\right]\left[1-k_{y j}\left(1-\frac{E T_{a}}{E T_{m}}\right)_{3}\right]
$$

where the subscripts 1,2, and 3 represent the first, second and third stages of growth and the other symbols retain the same meanings.

By putting $\frac{E T_{a}}{E T_{\max }}=1.0$ for the stages under full irrigation, and replacing $\frac{E T_{a}}{E T_{\max }}$ by stress coefficient $(k y)$ for the stage at which deficit irrigation was applied, we obtain:

$$
k_{y i}=\left(1-\frac{Y_{a i}}{Y_{\max }}\right)\left(1-k_{s i}\right)
$$

where the subscript $i$ denotes the stage at which deficit irrigation was implemented.

Table 5 shows the calculation of $k_{s}$ for different growth stages of sunflower at both locations. The obtained values of $k_{s}$ from Table 3 were used for calculating $k_{y}$ for different growth stages of sunflower genotypes. The study was focused on the stages of sunflower irrespective of genotype due to the soil moisture status under different genotypes.

The uniformity coefficient (UC) for some selected parameters was determined according to (Devitt et al., 1992): 


$$
\mathrm{UC}=1-(\text { Standard deviation } / \text { mean })
$$

\section{Laboratory analysis}

Table 6 shows the results of the investigated soil parameters. Particle size distribution for textural class assessing was carried out by international pipette method as described by Black et al. (1965). Hydrogen ion concentration $(\mathrm{pH})$ and electrical conductivity (EC) in a suspension ratio of $1: 10$, soil to $\mathrm{H}_{2} \mathrm{O}$ were determined by Thomas (1996), using pH model of WTW 330i, whereas for EC the model WTW 330i ECmeter was used. Organic carbon percentage $(\mathrm{O} . \mathrm{M} \%)$ in soil were determined by wet oxidation method according to the Walkley-Black method (Black et al.,1965). Then after the percent of organic matter was calculated through $\%$ Organic matter $=\%$ Organic carbon $\times 1.724$ (factor). Calcium carbonate $\mathrm{CaCO} 3 \%\left(\mathrm{~g} \mathrm{~kg}^{-1}\right)$ was determined according to a $23 \mathrm{c}$ method of U.S. Salinity Laboratory Staff, 1954 as mentioned in (Black et al., 1965).

Table 5. Calculation of stress coefficient during the stages when irrigation water skipped

\begin{tabular}{c|c|c|c|c|c|c|c|c|c}
\hline Locations & Stage & $\boldsymbol{\theta}_{\text {FC }}$ & $\boldsymbol{\theta}_{\mathbf{P W P}}$ & $\mathbf{T A W}$ & $\boldsymbol{\theta}$ & $(\mathbf{1 - P}) \mathbf{T A W}$ & $\begin{array}{c}\text { Depletion } \\
(\mathbf{D})\end{array}$ & $\mathbf{T A W}-\mathbf{D}$ & $\begin{array}{c}\text { Ks=(TAW- } \\
\text { D)/(1-P)TAW }\end{array}$ \\
\hline \multirow{3}{*}{ Kanipanka } & $\mathrm{S}_{1}$ & 0.303 & 0.196 & 0.107 & 0.221 & 0.05885 & 0.082 & 0.025 & 0.42 \\
& $\mathrm{~S}_{2}$ & 0.303 & 0.196 & 0.107 & 0.216 & 0.05885 & 0.087 & 0.02 & 0.34 \\
& $\mathrm{~S}_{3}$ & 0.303 & 0.196 & 0.107 & 0.207 & 0.05885 & 0.096 & 0.011 & 0.19 \\
\hline \multirow{3}{*}{ Qlyasan } & $\mathrm{S}_{1}$ & 0.302 & 0.195 & 0.107 & 0.219 & 0.05885 & 0.083 & 0.024 & 0.41 \\
& $\mathrm{~S}_{2}$ & 0.302 & 0.195 & 0.107 & 0.220 & 0.05885 & 0.082 & 0.025 & 0.42 \\
& $\mathrm{~S}_{3}$ & 0.302 & 0.195 & 0.107 & 0.211 & 0.05885 & 0.091 & 0.016 & 0.27 \\
\hline
\end{tabular}

$\theta_{\mathrm{FC}}=$ Water retention at $-33 \mathrm{kPa}$ on mass basis $\left(\mathrm{kg} \mathrm{ha}^{-1)}, \theta_{\mathrm{PWP}}=\right.$ Water retention at $-1500 \mathrm{kPa}$ on mass basis $\left(\mathrm{kg} \mathrm{ha}^{-1}\right), \theta=$ Average water content of the root zone on a mass basis during the stage when irrigation was skipping $\left(\mathrm{kg} \mathrm{ha}^{-1}\right), T A W=$ Total available water $\left(\mathrm{kg} \mathrm{ha}^{-1}\right), P=$ Fraction of TAW that a crop can extract from the root zone without suffering water stress $=0.45, D=$ Root zone depletion, $K s=$ Stress coefficient

Table 6. Physicochemical properties of the soil samples for locations of the experiment

\begin{tabular}{c|c|c|c}
\hline \multirow{2}{*}{ Physicochemical properties } & \multicolumn{2}{|c}{ Locations } \\
\cline { 2 - 4 } & Sand & Kanipanka & Qlyasan \\
\hline \multirow{2}{*}{ Particles size distribution kg ${ }^{-1}$} & Silt & 529 & 87 \\
& Clay & 435 & 435 \\
& Texture & $\mathrm{SiC}$ & 458 \\
PH & & 7.70 & $\mathrm{SiC}$ \\
\hline ECe (micro siemens cm & or $\left(\mu \mathrm{S} \mathrm{cm}^{-1}\right)$ & 218 & 7.59 \\
O.M. $\left(\mathrm{g} \mathrm{kg}^{-1}\right)$ & 14.8 & 490 \\
CaCO3 $\left(\mathrm{g} \mathrm{kg}^{-1}\right)$ & 208.3 & 22.4 \\
\hline
\end{tabular}




\section{Statistical analysis}

All collected data were statistically analyzed using XLSTAT (2017). A direct comparison of treatments, the least significant difference test (LSD) at levels of 0.05 and 0.01 levels was used. The analysis of variance (ANOVA) was used for testing the main effects of deficit irrigation on sunflower genotypes.

\section{Results}

Table 7 shows that the response of the parameters, seed yield, irrigation water use efficiency, and water use efficiency was highly significant to the effect of skipping irrigation treatments (Appendix). As seen in this table the most sensitive stage of irrigation skipping at flowering stage $\left(\mathrm{I}_{2}\right)$ at both Kanipanka and Qlyasan locations in which produced the lowest value of these parameters which were $3258.652 \mathrm{~kg} \mathrm{ha}^{-1}$, 5.012 , and $7.160 \mathrm{~kg} \mathrm{ha}^{-1} \mathrm{~mm}^{-1}$ respectively at Kanipanka location, while it reached $3853.858 \mathrm{~kg} \mathrm{ha}^{-1}, 5.714$, and $8.791 \mathrm{~kg} \mathrm{ha}^{-1} \mathrm{~mm}^{-1}$ respectively at the Qlyasan location. Based on the average values of seed yields at both locations, during skipping irrigation the results showed that the $\mathrm{I}_{4}>\mathrm{I}_{1}>\mathrm{I}_{3}>\mathrm{I}_{2}$. The result indicates that the lowest value for irrigation water use efficiency and water use efficiency were obtained at the flowering stage $\left(\mathrm{I}_{2}\right)$ at both locations. The order of different growth stages of irrigation skipping for IWUE, and WUE was as follows: achene formation stage > vegetative stage $>$ flowering stage. The results confirm that the $\mathrm{I}_{2}$ and $\mathrm{I}_{3}$ offered the lowest and the highest effect in these two parameters respectively.

Table 7. Effect of skipping irrigation treatments on seed yield, irrigation water use efficiency, and water use efficiency at Kanipanka and Qlyasan locations

\begin{tabular}{c|c|c|c|c}
\hline Irrigation treatments & $\begin{array}{c}\text { Total applied } \\
\text { water } \\
(\mathbf{m m})\end{array}$ & $\begin{array}{c}\text { Seed yield } \\
\left(\mathbf{k g ~ h a}^{-1}\right)\end{array}$ & $\begin{array}{c}\text { Irrigation water } \\
\text { use efficiency } \\
\text { IWUE } \\
\left(\mathbf{k g ~ h a}^{-1} \mathbf{~ m m}^{-1}\right)\end{array}$ & $\begin{array}{c}\text { Water use } \\
\text { efficiency } \\
\text { WUE } \\
\left(\mathbf{k g ~ h a}^{-1} \mathbf{~ m m}^{-\mathbf{1}}\right)\end{array}$ \\
\hline \multicolumn{5}{c}{ Kanipanka Location } \\
\hline $\mathrm{I}_{1}$ & 632.59 & $3842.512 \mathrm{~b}$ & $6.074 \mathrm{~b}$ & $8.677 \mathrm{~b}$ \\
$\mathrm{I}_{2}$ & 650.19 & $3258.652 \mathrm{~d}$ & $5.012 \mathrm{~d}$ & $7.160 \mathrm{~d}$ \\
$\mathrm{I}_{3}$ & 531.85 & $3544.538 \mathrm{c}$ & $6.664 \mathrm{a}$ & $9.521 \mathrm{a}$ \\
$\mathrm{I}_{4}$ & 761.3 & $4159.478 \mathrm{a}$ & $5.463 \mathrm{c}$ & $7.805 \mathrm{c}$ \\
$\mathrm{LSD}_{0.05}$ & \multicolumn{5}{c}{$175.104^{* *}$} & $0.265^{* *}$ & $0.379^{* *}$ \\
\hline \multicolumn{5}{|c|}{ Qlyasan Location } \\
\hline $\mathrm{I}_{1}$ & 648.15 & $4264.867 \mathrm{~b}$ & $6.580 \mathrm{~b}$ & $10.123 \mathrm{~b}$ \\
$\mathrm{I}_{2}$ & 674.44 & $3853.858 \mathrm{~d}$ & $5.714 \mathrm{c}$ & $8.791 \mathrm{c}$ \\
$\mathrm{I}_{3}$ & 494.26 & $4031.335 \mathrm{c}$ & $8.156 \mathrm{a}$ & $12.548 \mathrm{a}$ \\
$\mathrm{I}_{4}$ & 754.26 & $4734.582 \mathrm{a}$ & $6.277 \mathrm{bc}$ & $9.657 \mathrm{bc}$ \\
$\mathrm{LSD}_{0} 0.05$ & $385.936^{* *}$ & $0.684^{* *}$ & $1.053^{* *}$ \\
\hline
\end{tabular}

As shown in Table 8, a highly significant difference among the sunflower genotypes for seed yield, as related to IWUE, and WUE at both locations (Appendix). In relation to irrigation water use efficiency and water use efficiency, Velko genotype seed yields were higher values at Kanipanka location were $4405.035 \mathrm{~kg} \mathrm{ha}^{-1}, 6.911$, and $9.873 \mathrm{~kg}$ 
$\mathrm{ha}^{-1} \mathrm{~mm}^{-1}$ respectively than at the Qlyasan location $5356.999 \mathrm{~kg} \mathrm{ha}^{-1}, 8.47$, and $13.03 \mathrm{~kg}$ $\mathrm{ha}^{-1} \mathrm{~mm}^{-1}$ respectively. Based on the average values of these parameters for both locations, regarding the genotype performance; the order of performance; Velko > Barolo RO > Local. The results indicated that the Velko and Local genotypes had the highest and lowest performance respectively.

Table 8. Averages of seed yield, irrigation water use efficiency, and water use efficiency of sunflower genotypes at Kanipanka and Qlyasan locations

\begin{tabular}{|c|c|c|c|}
\hline Sunflower genotypes & $\begin{array}{c}\text { Seed yield } \\
\left(\mathrm{kg} \mathrm{ha}^{-1}\right)\end{array}$ & $\begin{array}{c}\text { Irrigation water use } \\
\text { efficiency } \\
\text { IWUE } \\
\left(\mathrm{kg} \mathrm{ha}^{-1} \mathbf{~ m m}^{-1}\right)\end{array}$ & $\begin{array}{c}\text { Water use efficiency } \\
\text { WUE } \\
\left(\mathrm{kg} \mathrm{ha}^{-1} \mathbf{~ m m}^{-1}\right)\end{array}$ \\
\hline \multicolumn{4}{|c|}{ Kanipanka Location } \\
\hline Barolo RO & $3431.935 \mathrm{~b}$ & $5.384 \mathrm{~b}$ & $7.692 \mathrm{~b}$ \\
\hline Velko & $4405.035 \mathrm{a}$ & $6.911 \mathrm{a}$ & $9.873 \mathrm{a}$ \\
\hline Local & $3266.915 \mathrm{c}$ & $5.115 \mathrm{c}$ & $7.308 \mathrm{c}$ \\
\hline LSD 0.05 & $118.837 * *$ & $0.180 * *$ & $0.257 * *$ \\
\hline \multicolumn{4}{|c|}{ Qlyasan Location } \\
\hline Barolo RO & $3809.474 \mathrm{~b}$ & $6.075 \mathrm{~b}$ & $9.347 \mathrm{~b}$ \\
\hline Velko & 5356.999 a & $8.470 \mathrm{a}$ & $13.03 \mathrm{a}$ \\
\hline Local & $3497.009 \mathrm{c}$ & $5.501 \mathrm{c}$ & $8.463 \mathrm{c}$ \\
\hline LSD 0.05 & $250.958 * *$ & $0.385 * *$ & $0.592 * *$ \\
\hline
\end{tabular}

There were statistically significant differences in seed yield among the sunflower genotypes under different irrigation treatments (Table 9 and Appendix). The flowering and achene formation stage respectively were the most sensitive stage to water deficit, which had a considerable yield decreases at both locations. It is evident from this table that at Kanipanka location Barolo RO genotype had the lowest yield of $2952.785 \mathrm{~kg} \mathrm{ha}^{-1}$ under $\mathrm{I}_{2}$ treatment, while at the Qlyasan location the local genotype showed the lowest seed yield of $3117.805 \mathrm{~kg} \mathrm{ha}^{-1}$ under $\mathrm{I}_{3}$ treatment. Seed yield increased with increasing amount of applied irrigation water quantities, for instance, Velko genotype gave the highest seed yield under full irrigation treatment $\left(\mathrm{I}_{4}\right)$ at both locations 4993.705 and $6247.265 \mathrm{~kg} \mathrm{ha}^{-1}$ respectively.

As seen in this table the irrigation water use efficiency and water use efficiency restricted from as low as 4.541 and $6.488 \mathrm{~kg} \mathrm{ha}^{-1} \mathrm{~mm}^{-1}$ respectively at first location for the Barolo RO genotype under $\mathrm{I}_{2}$ treatment, while as high as 10.347 and $15.918 \mathrm{~kg} \mathrm{ha}^{-1}$ $\mathrm{mm}^{-1}$ respectively for the Velko genotype under $\mathrm{I}_{3}$ irrigation treatment at the second location. The results above stated that both IWUE and WUE values decreased with increasing irrigation water quantities except full irrigation $\left(\mathrm{I}_{4}\right)$.

Table 10 represents a yield response $(\mathrm{ky})$ factor for three individual sunflower growth stages. The crop response factor value varies depending on season, location and intensity of water deficit. Among three sunflower genotypes and water deficit at different growth stages at both study locations, the highest crop response factor $(k y)$ value was found at flowering stage $\left(S_{2}\right)$, followed by achene formation $\left(S_{3}\right)$ and vegetative $\left(S_{1}\right)$ stages at Kanipanka and Qlyasan locations respectively.

The yield response factor $k y$ of $0.366,0.350$, and 0.253 was found at $\mathrm{S}_{2}$ for Velko, Barolo RO, and Local genotypes respectively at Kanipanka location. The water stress at 
$\mathrm{S}_{1}$ and $\mathrm{S}_{3}$ exerted (56.83 and 53.28\%; 73.43 and 50.86\%; and 44.66 and $18.18 \%$ ) respectively, less stress than most stressed treatment $S_{2}$.

At Qlyasan location, the yield response factor $k y$ of $0.426,0.338$ and 0.144 was found at $\mathrm{S}_{2}$ for Velko, Local, and Barolo RO genotype. The water stress at $\mathrm{S}_{1}$ and $\mathrm{S}_{3}$ exerted (43.19 and 41.55\%; 39.35 and $6.51 \%$; and 93.75 and $89.58 \%$ ) respectively, less than the most stressed treatment $S_{2}$.

Therefore, the order of sensitive stages to water deficit arrangement for individual growth stages can be written at both locations as follows: $S_{2}>S_{3}>S_{1}$ for all of the genotypes.

Table 9. Seed yield, irrigation water use efficiency, and water use efficiency of three sunflower genotypes as influenced by different irrigation treatments at both locations

\begin{tabular}{|c|c|c|c|c|c|c|c|}
\hline \multirow{2}{*}{\multicolumn{2}{|c|}{$\begin{array}{c}\text { Sunflower } \\
\text { genotypes and } \\
\text { irrigation } \\
\text { treatments }\end{array}$}} & \multicolumn{3}{|c|}{ Total applied water } & \multirow[b]{2}{*}{$\begin{array}{c}\text { Seed yield } \\
\left(\mathrm{kg} \mathrm{ha}^{-1}\right)\end{array}$} & \multirow{2}{*}{$\begin{array}{c}\text { Irrigation } \\
\text { water use } \\
\text { efficiency } \\
(\text { IWUE) } \\
\left(\mathrm{kg} \mathrm{ha}^{-1} \mathbf{~ m m}^{-1}\right)\end{array}$} & \multirow{2}{*}{$\begin{array}{c}\text { Water use } \\
\text { efficiency } \\
(\text { WUE) } \\
\left(\mathbf{k g ~ h a}^{-1} \mathbf{~ m m}^{-1}\right)\end{array}$} \\
\hline & & $(\mathbf{m m})$ & $\left(\mathbf{m}^{3} \mathbf{h a}^{-1}\right)$ & $\begin{array}{c}\mathbf{E T}_{\mathrm{a}} \\
\left(\mathbf{m}^{\mathbf{3}} \mathbf{h a}^{-1}\right)\end{array}$ & & & \\
\hline \multicolumn{8}{|c|}{ Kanipanka Location } \\
\hline \multirow{4}{*}{$\begin{array}{l}\text { Barolo } \\
\text { RO }\end{array}$} & $\mathrm{I}_{1}$ & 632.59 & 6325.93 & 4428.148 & $3633.770 \mathrm{~d}$ & $5.744 \mathrm{~d}$ & $8.206 \mathrm{~d}$ \\
\hline & $\mathrm{I}_{2}$ & 650.19 & 6501.85 & 4551.296 & $2952.785 \mathrm{f}$ & $4.541 \mathrm{~g}$ & $6.488 \mathrm{~g}$ \\
\hline & $\mathrm{I}_{3}$ & 531.85 & 5318.52 & 3722.963 & $3302.435 \mathrm{e}$ & $6.209 \mathrm{c}$ & $8.87 \mathrm{c}$ \\
\hline & $\mathrm{I}_{4}$ & 761.3 & 7612.96 & 5329.074 & $3838.750 \mathrm{~d}$ & $5.042 \mathrm{ef}$ & $7.203 \mathrm{ef}$ \\
\hline \multirow{4}{*}{ Velko } & $\mathrm{I}_{1}$ & 632.59 & 6325.93 & 4428.148 & $4541.010 \mathrm{~b}$ & $7.178 \mathrm{~b}$ & $10.255 \mathrm{~b}$ \\
\hline & $\mathrm{I}_{2}$ & 650.19 & 6501.85 & 4551.296 & $3786.950 \mathrm{~d}$ & $5.824 \mathrm{~d}$ & $8.321 \mathrm{~d}$ \\
\hline & $\mathrm{I}_{3}$ & 531.85 & 5318.52 & 3722.963 & $4298.475 \mathrm{c}$ & $8.082 \mathrm{a}$ & $11.546 \mathrm{a}$ \\
\hline & $\mathrm{I}_{4}$ & 761.3 & 7612.96 & 5329.074 & $4993.705 \mathrm{a}$ & $6.559 \mathrm{c}$ & $9.371 \mathrm{c}$ \\
\hline \multirow{4}{*}{ Local } & $\mathrm{I}_{1}$ & 632.59 & 6325.93 & 4428.148 & $3352.755 \mathrm{e}$ & $5.3 \mathrm{e}$ & $7.571 \mathrm{e}$ \\
\hline & $\mathrm{I}_{2}$ & 650.19 & 6501.85 & 4551.296 & $3036.220 \mathrm{f}$ & $4.67 \mathrm{~g}$ & $6.671 \mathrm{~g}$ \\
\hline & $\mathrm{I}_{3}$ & 531.85 & 5318.52 & 3722.963 & $3032.705 \mathrm{f}$ & $5.702 \mathrm{~d}$ & $8.146 \mathrm{~d}$ \\
\hline & $\mathrm{I}_{4}$ & 761.3 & 7612.96 & 5329.074 & $3645.980 \mathrm{~d}$ & $4.789 \mathrm{fg}$ & $6.842 \mathrm{fg}$ \\
\hline \multicolumn{5}{|c|}{$L S D 0.05$} & $237.673 *$ & $0.359 * *$ & $0.513^{*}$ \\
\hline \multicolumn{8}{|c|}{ Qlyasan Location } \\
\hline \multirow{4}{*}{$\begin{array}{c}\text { Barolo } \\
\text { RO }\end{array}$} & $\mathrm{I}_{1}$ & 648.15 & 6481.48 & 4212.963 & $3885.74 \mathrm{~d}$ & $5.995 \mathrm{de}$ & $9.223 \mathrm{de}$ \\
\hline & $\mathrm{I}_{2}$ & 674.44 & 6744.44 & 4383.889 & $3583.635 \mathrm{de}$ & $5.313 \mathrm{ef}$ & 8.175 ef \\
\hline & $\mathrm{I}_{3}$ & 494.26 & 4942.59 & 3212.685 & $3862.245 \mathrm{~d}$ & $7.814 \mathrm{~b}$ & $12.022 \mathrm{~b}$ \\
\hline & $\mathrm{I}_{4}$ & 754.26 & 7542.59 & 4902.685 & $3906.275 \mathrm{~d}$ & $5.179 \mathrm{f}$ & $7.968 \mathrm{f}$ \\
\hline \multirow{4}{*}{ Velko } & $\mathrm{I}_{1}$ & 648.15 & 6481.48 & 4212.963 & $5351.125 \mathrm{~b}$ & $8.256 \mathrm{~b}$ & $12.702 \mathrm{~b}$ \\
\hline & $\mathrm{I}_{2}$ & 674.44 & 6744.44 & 4383.889 & $4715.65 \mathrm{c}$ & $6.992 \mathrm{c}$ & $10.757 \mathrm{c}$ \\
\hline & $\mathrm{I}_{3}$ & 494.26 & 4942.59 & 3212.685 & $5113.955 \mathrm{bc}$ & $10.347 \mathrm{a}$ & $15.918 \mathrm{a}$ \\
\hline & $\mathrm{I}_{4}$ & 754.26 & 7542.59 & 4902.685 & $6247.265 \mathrm{a}$ & $8.283 \mathrm{~b}$ & $12.743 \mathrm{~b}$ \\
\hline \multirow{4}{*}{ Local } & $\mathrm{I}_{1}$ & 648.15 & 6481.48 & 4212.963 & $3557.735 \mathrm{de}$ & $5.489 \mathrm{ef}$ & 8.445 ef \\
\hline & $\mathrm{I}_{2}$ & 674.44 & 6744.44 & 4383.889 & $3262.29 \mathrm{e}$ & $4.837 \mathrm{f}$ & $7.442 \mathrm{f}$ \\
\hline & $\mathrm{I}_{3}$ & 494.26 & 4942.59 & 3212.685 & $3117.805 \mathrm{e}$ & $6.308 \mathrm{~cd}$ & $9.705 \mathrm{~cd}$ \\
\hline & $\mathrm{I}_{4}$ & 754.26 & 7542.59 & 4902.685 & $4050.205 \mathrm{~d}$ & $5.37 \mathrm{ef}$ & $8.261 \mathrm{ef}$ \\
\hline \multicolumn{5}{|c|}{$L S D 0.05$} & $501.915^{*}$ & $0.770^{*}$ & $1.184^{*}$ \\
\hline
\end{tabular}


Table 10. Crop response factor (ky) for individual Sunflower growth stages at which irrigation was skipped at both locations

\begin{tabular}{|c|c|c|c|c|c|c|c|c|c|}
\hline Locations & \begin{tabular}{|c|}
$\begin{array}{c}\text { Sunflower } \\
\text { genotype }\end{array}$ \\
\end{tabular} & $\begin{array}{c}\begin{array}{c}\text { Sunflower } \\
\text { growth stage }\end{array} \\
\end{array}$ & $\mathbf{Y}$ & $\mathbf{Y}_{\max }$ & $\mathbf{Y} / \mathbf{Y}_{\mathbf{m}}$ & $1-\mathbf{Y} / \mathbf{Y}_{\mathrm{m}}$ & $\mathbf{K}_{\mathrm{s}}$ & $1-K s$ & $\begin{array}{c}\mathbf{K}_{\mathbf{Y}}= \\
\left(1-\mathbf{Y} / \mathbf{Y}_{\mathbf{m}}\right) /\left(1-K_{s}\right)\end{array}$ \\
\hline \multirow{9}{*}{ Kanipanka } & \multirow{3}{*}{$\begin{array}{c}\text { Barolo } \\
\text { RO }\end{array}$} & $\mathrm{S}_{1}$ & 3633.77 & 3838.75 & 0.947 & 0.053 & 0.425 & 0.575 & 0.093 \\
\hline & & $\mathrm{S}_{2}$ & 2952.79 & 3838.75 & 0.769 & 0.231 & 0.340 & 0.660 & 0.350 \\
\hline & & $\mathrm{S}_{3}$ & 3302.44 & 3838.75 & 0.860 & 0.140 & 0.187 & 0.813 & 0.172 \\
\hline & \multirow{3}{*}{ Velko } & $S_{1}$ & 4541.01 & 4993.71 & 0.909 & 0.091 & 0.425 & 0.575 & 0.158 \\
\hline & & $\mathrm{S}_{2}$ & 3786.95 & 4993.71 & 0.758 & 0.242 & 0.340 & 0.660 & 0.366 \\
\hline & & $\mathrm{S}_{3}$ & 4298.48 & 4993.71 & 0.861 & 0.139 & 0.187 & 0.813 & 0.171 \\
\hline & \multirow{3}{*}{ Local } & $\mathrm{S}_{1}$ & 3352.76 & 3645.98 & 0.920 & 0.080 & 0.425 & 0.575 & 0.140 \\
\hline & & $\mathrm{S}_{2}$ & 3036.22 & 3645.98 & 0.833 & 0.167 & 0.340 & 0.660 & 0.253 \\
\hline & & $\mathrm{S}_{3}$ & 3032.71 & 3645.98 & 0.832 & 0.168 & 0.187 & 0.813 & 0.207 \\
\hline & & & & & & & & & $S E=0.031$ \\
\hline \multirow{9}{*}{ Qlyasan } & \multirow{3}{*}{$\begin{array}{c}\text { Barolo } \\
\text { RO }\end{array}$} & $\mathrm{S}_{1}$ & 3885.74 & 3906.28 & 0.995 & 0.005 & 0.408 & 0.592 & 0.009 \\
\hline & & $\mathrm{S}_{2}$ & 3583.64 & 3906.28 & 0.917 & 0.083 & 0.425 & 0.575 & 0.144 \\
\hline & & $\mathrm{S}_{3}$ & 3862.25 & 3906.28 & 0.989 & 0.011 & 0.272 & 0.728 & 0.015 \\
\hline & \multirow{3}{*}{ Velko } & $\mathrm{S}_{1}$ & 5351.13 & 6247.27 & 0.857 & 0.143 & 0.408 & 0.592 & 0.242 \\
\hline & & $\mathrm{S}_{2}$ & 4715.65 & 6247.27 & 0.755 & 0.245 & 0.425 & 0.575 & 0.426 \\
\hline & & $\mathrm{S}_{3}$ & 5113.96 & 6247.27 & 0.819 & 0.181 & 0.272 & 0.728 & 0.249 \\
\hline & \multirow{3}{*}{ Local } & $\mathrm{S}_{1}$ & 3557.74 & 4050.21 & 0.878 & 0.122 & 0.408 & 0.592 & 0.205 \\
\hline & & $\mathrm{S}_{2}$ & 3262.29 & 4050.21 & 0.805 & 0.195 & 0.425 & 0.575 & 0.338 \\
\hline & & $\mathrm{S}_{3}$ & 3117.81 & 4050.21 & 0.770 & 0.230 & 0.272 & 0.728 & 0.316 \\
\hline & & & & & & & & & $S E=0.047$ \\
\hline
\end{tabular}

The highest value of $k y$ were $0.366,0.350$ and 0.253 at the first location, while it was $0.426,0.144$ and 0.338 at the second locations, for Velko, Barolo RO and Local genotype by imposing water deficit at critical growth stages (flowering stage).

Data represented in Table 11 illustrate the crop yield response factor $(k y)$ for sunflower genotypes at both locations, which estimated according to Doorenbos and Kassam (1979), the results were tabulated in this table. The crop response factor values ranged from the minimum of 0.089 for the Barolo RO genotype at the Qlyasan location to a maximum of 0.781 for the Local genotype at the same location. Also, among the genotypes, Barolo RO exhibited the least value of $(\mathrm{ky})$ at both locations. All genotypes yield response factor were of less than 1.0.

Table 11. Crop response factor for different sunflower genotypes to limited irrigation at both locations

\begin{tabular}{|c|c|c|c|c|}
\hline Locations & $\begin{array}{l}\text { Sunflower } \\
\text { genotypes }\end{array}$ & $\begin{array}{c}\text { Seed yield } \\
\left(\mathrm{kg} \mathrm{ha}^{-1}\right)\end{array}$ & $\begin{array}{c}E T_{a} \\
\left(\mathbf{m}^{3} \mathbf{h a}^{-1}\right)\end{array}$ & $k y$ \\
\hline \multirow{3}{*}{ Kanipanka } & Barolo RO & $3431.935 \mathrm{~b}$ & 4507.87 & 0.603 \\
\hline & Velko & $4405.035 \mathrm{a}$ & 4507.87 & 0.658 \\
\hline & Local & $3266.915 \mathrm{~b}$ & 4507.87 & 0.630 \\
\hline & & $L S D .05175 .104$ & & $S E=0.016$ \\
\hline \multirow{3}{*}{ Qlyasan } & Barolo RO & $3809.474 \mathrm{~b}$ & 4178.056 & 0.089 \\
\hline & Velko & $5356.999 \mathrm{a}$ & 4178.056 & 0.725 \\
\hline & Local & $3497.009 \mathrm{~b}$ & 4178.056 & 0.781 \\
\hline & & $L S D .05385 .936$ & & $S E=0.222$ \\
\hline
\end{tabular}


Table 12 illustrate the yield reduction and water saving for sunflower genotypes under different irrigation treatments. It was shown that the percent yield reduction decreased with an increase in the amount of applied water at various growth stages. The maximum percentage of yield reduction was 24.17 and $24.52 \%$ for Velko genotype under skipping irrigation at flowering stage $\left(\mathrm{I}_{2}\right)$ at both locations, respectively. Deficit irrigations applied in vegetative stages have fewer effects on seed yield losses, while the effects were higher at flowering and achene formation stages. Also, seed yields were affected by water stress at later growth stages, which could result in about $40 \%$ water saving as compared with full irrigation.

Table 12. Percent of yield reduction and water saving under limited irrigation of both locations

\begin{tabular}{|c|c|c|c|c|c|}
\hline \multicolumn{2}{|c|}{$\begin{array}{c}\text { Genotypes and irrigation } \\
\text { treatments }\end{array}$} & $\begin{array}{c}\text { Total applied } \\
\text { water }(\mathbf{m m})\end{array}$ & $\begin{array}{c}\begin{array}{c}\text { Seed yield } \\
\left(\mathrm{kg} \mathrm{ha}^{-1}\right)\end{array} \\
\end{array}$ & $\begin{array}{c}\text { Yield } \\
\text { reduction \% }\end{array}$ & $\begin{array}{c}\text { Water saving } \\
\quad \%\end{array}$ \\
\hline \multicolumn{6}{|c|}{ Kanipanka Location } \\
\hline \multirow{4}{*}{$\begin{array}{l}\text { Barolo } \\
\text { RO }\end{array}$} & $\mathrm{I}_{1}$ & 632.59 & $3633.770 \mathrm{~d}$ & 5.34 & 16.91 \\
\hline & $\mathrm{I}_{2}$ & 650.19 & $2952.785 \mathrm{f}$ & 23.08 & 14.59 \\
\hline & $\mathrm{I}_{3}$ & 531.85 & $3302.435 \mathrm{e}$ & 13.97 & 30.14 \\
\hline & $\mathrm{I}_{4}$ & 761.3 & $3838.750 \mathrm{~d}$ & 0.00 & 0.00 \\
\hline \multirow{4}{*}{ Velko } & $\mathrm{I}_{1}$ & 632.59 & $4541.010 \mathrm{~b}$ & 9.07 & 16.91 \\
\hline & $\mathrm{I}_{2}$ & 650.19 & $3786.950 \mathrm{~d}$ & 24.17 & 14.59 \\
\hline & $\mathrm{I}_{3}$ & 531.85 & $4298.475 \mathrm{c}$ & 13.92 & 30.14 \\
\hline & $\mathrm{I}_{4}$ & 761.3 & $4993.705 \mathrm{a}$ & 0.00 & 0.00 \\
\hline \multirow{4}{*}{ Local } & $\mathrm{I}_{1}$ & 632.59 & $3352.755 \mathrm{e}$ & 8.04 & 16.91 \\
\hline & $\mathrm{I}_{2}$ & 650.19 & $3036.220 \mathrm{f}$ & 16.72 & 14.59 \\
\hline & $\mathrm{I}_{3}$ & 531.85 & $3032.705 \mathrm{f}$ & 16.82 & 30.14 \\
\hline & $\mathrm{I}_{4}$ & 761.3 & $3645.980 \mathrm{~d}$ & 0.00 & 0.00 \\
\hline \multirow{2}{*}{\multicolumn{6}{|c|}{\begin{tabular}{l|l} 
& LSD $_{0.05} 237.673 *$ \\
Qlyasan Location
\end{tabular}}} \\
\hline & & & & & \\
\hline \multirow{4}{*}{$\begin{array}{l}\text { Barolo } \\
\text { RO }\end{array}$} & $\mathrm{I}_{1}$ & 648.15 & $3885.74 \mathrm{~d}$ & 0.53 & 14.07 \\
\hline & $\mathrm{I}_{2}$ & 674.44 & $3583.635 \mathrm{de}$ & 8.26 & 10.58 \\
\hline & $\mathrm{I}_{3}$ & 494.26 & $3862.245 \mathrm{~d}$ & 1.13 & 34.47 \\
\hline & $\mathrm{I}_{4}$ & 754.26 & $3906.275 \mathrm{~d}$ & 0.00 & 0.00 \\
\hline \multirow{4}{*}{ Velko } & $\mathrm{I}_{1}$ & 648.15 & $5351.125 \mathrm{~b}$ & 14.34 & 14.07 \\
\hline & $\mathrm{I}_{2}$ & 674.44 & $4715.65 \mathrm{c}$ & 24.52 & 10.58 \\
\hline & $\mathrm{I}_{3}$ & 494.26 & $5113.955 \mathrm{bc}$ & 18.14 & 34.47 \\
\hline & $\mathrm{I}_{4}$ & 754.26 & $6247.265 \mathrm{a}$ & 0.00 & 0.00 \\
\hline \multirow{4}{*}{ Local } & $\mathrm{I}_{1}$ & 648.15 & $3557.735 \mathrm{de}$ & 12.16 & 14.07 \\
\hline & $\mathrm{I}_{2}$ & 674.44 & $3262.29 \mathrm{e}$ & 19.45 & 10.58 \\
\hline & $\mathrm{I}_{3}$ & 494.26 & $3117.805 \mathrm{e}$ & 23.02 & 34.47 \\
\hline & $\mathrm{I}_{4}$ & 754.26 & $4050.205 \mathrm{~d}$ & 0.00 & 0.00 \\
\hline & & & $\mathrm{LSD}_{0.05} 501.915^{*}$ & $S E=2.794$ & \\
\hline
\end{tabular}

As listed in Table 13, the uniformity coefficient values were 0.93 for Velko genotype, and it was below this value for the Barolo RO and Local genotype. Also, there was a statistical difference between genotypes and locations data. 
Table 13. Yield response factor (Ky) of sunflower genotypes under different irrigation treatments

\begin{tabular}{|c|c|c|c|c|c|c|c|c|}
\hline \multirow{2}{*}{$\begin{array}{l}\text { Sunflower } \\
\text { genotypes }\end{array}$} & \multicolumn{2}{|c|}{$\begin{array}{c}E T_{a} \\
\left(\mathbf{m}^{3} \mathbf{h a}^{-1}\right)\end{array}$} & \multicolumn{3}{|c|}{ Ky value } & \multirow{2}{*}{$\begin{array}{c}\text { Standard } \\
\text { deviation } \\
\text { (SD) }\end{array}$} & \multirow{2}{*}{$\begin{array}{l}\text { Uniformity } \\
\text { coefficient } \\
\text { (UC) }\end{array}$} & \multirow{2}{*}{$\begin{array}{c}\text { Coefficient } \\
\text { of variance } \\
\text { (CV) \% }\end{array}$} \\
\hline & \begin{tabular}{c|} 
Kanipanka \\
location
\end{tabular} & $\begin{array}{l}\text { Qlyasan } \\
\text { location }\end{array}$ & $\begin{array}{c}\text { Kanipanka } \\
\text { location }\end{array}$ & $\begin{array}{l}\text { Qlyasan } \\
\text { location }\end{array}$ & \begin{tabular}{|c|}
$\mathrm{Ky}$ \\
mean
\end{tabular} & & & \\
\hline $\begin{array}{c}\text { Barolo } \\
\text { RO }\end{array}$ & 4507.87 & 4178.056 & 0.6028 & & 0.346 & & -0.04962 & 104.96 \\
\hline Velko & 4507.87 & 4178.056 & 0.6577 & 0.7253 & 0.6915 & 0.0478 & 0.930874 & 6.913 \\
\hline Local & 4507.87 & 4178.056 & 0.6303 & 0.7813 & 0.7058 & 0.106773 & 0.84872 & 15.128 \\
\hline
\end{tabular}

\section{Discussion}

The lowest and highest seed yields under irrigation water use efficiency (IWUE) and water use efficiency (WUE) at both $\mathrm{I}_{2}$ and $\mathrm{I}_{3}$ stages were due to a deficit in irrigation. This may be due the effect of deficit irrigation. Therefore, such effect could be less significant if water stress were applied to the crop during specific growth stages that were less sensitive to moisture deficiency. Kazemeini et al. (2009) also reached the same conclusions. Also, Iqbal et al. (2005) reported that flowering and seed filling stages had been the most critical for water stress in sunflower. Therefore, Anastasi et al. (2010) signified that sunflower provides the highest seed yield under full irrigation.

Genotypes and irrigation stages were the main factors in higher seed yields of Velko genotype. Our results collaborate (Mahender et al., 2000; Kakar and Soomro, 2001) results in which genotypes and irrigation intervals are two main factors in seed yield increases in oilseed sunflower. Various genotypes of sunflower have different responses to water stress. Our results were similar to (Angadi and Entz, 2002; Bakht et al., 2010) who observed the genotypic differences in sunflower for drought tolerance.

Velko genotype produced the highest seed yields under full irrigation $\left(\mathrm{I}_{4}\right)$, and drought stress statically decreased seed yield compared to no-stress. This indicates that skipping of irrigation at these stages can minimize seed yield to a great extent. Irrigation skipping at the achene formation stage $\left(\mathrm{I}_{3}\right)$ should be preferred due to higher IWUE and WUE if water resources are limited. Our finding collaborates (Cicek et al., 2015; Baba et al., 2016). The results stated that there is a steady decrease in both irrigation water use efficiency and water use efficiency with an increase in the amount of water quantities with the exception of control treatment $\left(\mathrm{I}_{4}\right)$. Our study showed that IWUE and WUE values were higher than those in literature in the neighboring countries under limited irrigation. Kassab et al. (2012) found that the WUE under drought condition higher than it is under plain irrigation. Regarding the genotypes, the second and third stage, i.e., skipped irrigation at flowering and achene formation stages are the critical stages for deficit irrigation. Therefore, skipping of irrigation at these stages can minimize crop yield to a great extent. Irrigation skipping at the achene formation stage should be preferred due to higher IWUE and WUE when water resources are limited, and the cost of irrigation water is high.

The crop response $(k y)$ factor value for individual growth stages varies depending on season, location and intensity of water deficit. Among three sunflower genotypes and water deficit at different growth stages, the highest crop response factor value was found at flowering $\left(S_{2}\right)$, followed by achene formation $\left(S_{3}\right)$ and vegetative $\left(S_{1}\right)$ stages. This may explain that the flowering stage is critical in sunflower seed production. 
Therefore, the water deficit at flowering stage must be avoided if possible. Martyniak (2008) stated that drought tolerance differs strongly among the growth stages of many crops. Thus, water stress at flowering stage $\left(S_{2}\right)$ will not be allowed because of yield reduction was found higher than other stages (Table 12). The flowering stage was the most critical stage to deficit irrigation for sunflower cultivation. The flowering stage is the most sensitive to water deficits which cause considerable seed yield decreases since fewer flower come to full development (Beyazgul et al., 2000; Ali and Shui, 2009). Water deficit at the flowering stage should be avoided. It is clear that the value of response factor varies from location to location (depending on weather and soil), variety to variety, crop to crop, season to season and also for individual growth stages to entire growing season what Ali (2009) discussed in determining response factor of winter wheat in Bangladesh.

The crop response factor $(k y)$ value for the entire cropping season was determined by Doorenbos and Kassam (1979). Several research reports exist on yield response of sunflower to water, while other reported that the $(k y)$ values were between $0.80-0.95$ for sunflower (Demir et al., 2006; Moutonnet, 2002). But, Mila and Ali (2016) found that the $(\mathrm{ky})$ values were in the range of 0.25 to 0.64 for the whole growing season of sunflower. Similarly, (Sullu and Dagdelen, 2015) reported that the crop response factor as 0.74 for the entire growth season. However, our $k y$ values for all genotypes were between $0.09-0.78$. This confirmed that the genotypes under our study are more tolerant to water deficit, and partly recovering from stress, exhibiting less than relative reductions in yield with reduced water use. Regarding the previous studies, there are agreements $(k y<1)$ (Silva et al., 2014; Steduto et al., 2012) and divergences $(k y>1)$ (Sezen et al., 2011), with respect to tolerance sunflower. However, slight differences in yield response factors were mainly because of differences in climate parameters, plant water consumptions, cultivars, soil conditions, irrigation programs and other cultural practices (Çiçek et al., 2015).

The maximum percentage of seed yield reduction was recorded by Velko genotype under skipping irrigation at flowering stage $\left(\mathrm{I}_{2}\right)$ treatment at both locations. This confirmed that the most sensitive stage to water deficit is a flowering stage, which similar to the result reported by Shafi et al. (2013) who indicated a considerable reduction in seed yield of sunflower due to water stress at the flowering stage. Therefore, plant growth stages should be taken into consideration, and irrigation scheduling should accordingly be created to have optimum water use efficiency in semiarid climates.

It was noticed that the highest uniformity coefficient value recorded by Velko genotype, compared to the values of Barolo RO and Local genotypes, could be due to various factors such as growing season, region and intensity of water deficit (Mila and Ali, 2016).

The study showed that the most active growth stage of irrigation was skipping irrigation at flowering stage, compared with other stages; therefore irrigation during this period would ensure the least yield reduction of sunflower. This implies that irrigation treatment at the middle stage was more efficient to increase the seed yield of sunflower genotypes rather than the early and last irrigation. The tolerance of the full-grown plant to drought may be due to sufficient root penetration without water deficit in the early stages of growth. Also, the increase in the production of antioxidant enzymes when plants are subjected to stress may also provide plant resistance to drought (Langeroodi et al., 2014). 


\section{Conclusion}

The results indicated that skipping irrigation at the flowering stage was more effective to decrease the seed yield of sunflower genotypes than the achene formation and vegetative stages; it is the most sensitive stage to water deficit which causes considerable yield reduction. It was observed that the water deficit should be avoided at the flowering stage. Thus, water must be ensured at this stage to prevent severe yield loss. Greater water stress may be contributed to higher crop response factor, which indicated that sufficient water supply during flowering and achene formation stage is important. The results showed that water deficit at the flowering stage should be eliminated. However, this will change with location, the intensity of water deficit, and stages of growth. Water stress can influence seed yield in sunflower during the stages of flowering and seed formation due to its effect on reproductive organs and the increase in the number of empty seeds; this may be due to abortion of ovaries, embryo, and sterility of pollen grains.

In view of the existing values of water efficiency, it is recommended to give high priority to Velko genotype coupled with none skipping irrigation at the flowering stage.

\section{REFERENCES}

[1] Abou El-Seoud, I. I. A., Wafaa, H. M. (2010): Phosphorus efficiency of different maize (Zea mays, L.) genotypes grown on calcareous soil. - Alex. Sci. Exch. J. 31(1): 1-9.

[2] Ahmed, M. A., Hassanein, M. E. S. (2000): Partition of photosynthates in yellow maize hybrids. - Egyptian Journal of Agronomy 22: 39-63.

[3] Allen, R. G., Pereira, L. S., Raes, D., Smith, M. (1998): Crop evapotranspirationGuidelines for computing crop water requirements. - FAO Irrigation and Drainage Paper 56. Fao, Rome 300(9): D05109.

[4] Ali, M. H. (2009): Irrigation-yield response factor of winter wheat for different growth phases. - Journal of Agrometeorology 11(1): 9-14.

[5] Ali, M. H., Shui, L. T. (2009): Potential evapotranspiration model for Muda irrigation project, Malaysia. - Water Resources Management 23(1): 57.

[6] Anastasi, U., Santonoceto, C., Giuffrè, A. M., Sortino, O., Gresta, F., Abbate, V. (2010): Yield performance and grain lipid composition of standard and oleic sunflower as affected by water supply. - Field Crops Research 119(1): 145-153.

[7] Angadi, S. V., Entz, M. H. (2002): Water relations of standard height and dwarf sunflower cultivars. - Crop Science 42(1): 152-159.

[8] Baba, H., Zumre, M., Ozyigit, I. I. (2016): A comparative biogeographical study of myxomycetes in four different habitats of eastern Mediterranean part of Turkey. Fresenius Environmental Bulletin 25(5): 1449-1460.

[9] Bakht, J., Shafi, M., Yousaf, M., Raziuddin, K. M., Khan, M. A. (2010): Effect of irrigation on physiology and yield of sunflower hybrids. - Pak. J. Bot 42(2): 1317-1326.

[10] Bashir, M. A., Mohamed, Y. M. (2014): Evaluation of full and deficit irrigation on two sunflower hybrids under semi-arid environment of Gezira, Sudan. - Journal of Agri-Food and Applied Sciences 2(3): 53-59.

[11] Beg, A., Pourdad, S. S., Alipour, S. (2007): Row and plant spacing effects on agronomic performance of sunflower in warm and semi-cold areas of Iran. - Helia 30(47): 99-104.

[12] Beyazgül, M., Kayam, Y., Engelsman, F. (2000): Estimation methods for crop water requirements in the Gediz Basin of western Turkey. - Journal of Hydrology 229(1-2): 1926.

[13] Black, C. A., Evans, D. D., Dinauer, R. C. (1965): Methods of Soil Analysis. Vol. 9. American Society of Agronomy, Madison, WI, pp. 653-708. 
[14] Çiçek, N., Arslan, Ö., Çulha-Erdal, Ş., Eyidoğan, F., Ekmekçi, Y. (2015): Are the photosynthetic performance indexes and the drought factor index satisfactory selection criterion for stress. - Fresen. Environ. Bull 24(11c): 4190-4198.

[15] De Pascale, S., Dalla Costa, L., Vallone, S., Barbieri, G., Maggio, A. (2011): Increasing water use efficiency in vegetable crop production: from plant to irrigation systems efficiency. - Hort Technology 21(3): 301-308.

[16] Demir, A. O., Göksoy, A. T., Büyükcangaz, H., Turan, Z. M., Köksal, E. S. (2006): Deficit irrigation of sunflower (Helianthus annuus L.) in a sub-humid climate. - Irrigation Science 24(4): 279-289.

[17] Devitt, D. A., Morris, R. L., Bowman, D. C. (1992): Evapotranspiration, crop coefficients, and leaching fractions of irrigated desert turfgrass systems. - Agronomy Journal 84(4): 717-723.

[18] Doorenbos, J., Kassam, A. H. (1979): Yield response to water. - Irrigation and Drainage Paper 33: 257.

[19] Fan, T., Stewart, B. A., Payne, W. A., Wang, Y., Song, S., Luo, J., Robinson, C. A. (2005): Supplemental irrigation and water-yield relationships for plasticulture crops in the Loess Plateau of China. - Agronomy Journal 97(1): 177-188.

[20] Faraji, A., Latifi, N., Soltani, A., Rad, A. H. S. (2009): Seed yield and water use efficiency of canola (Brassica napus L.) as affected by high-temperature stress and supplemental irrigation. - Agricultural Water Management 96(1): 132-140.

[21] Ghani, A., Hussain, M., Qureshi, M. S. (2000): Effect of different irrigation regimens on the growth and yield of sunflower. - International Journal of Agriculture and Biology 2(4): 334-335.

[22] González, J., Mancuso, N., Ludueña, P. (2013): Sunflower yield and climatic variables. Helia 36(58): 69-76.

[23] Ibrahim, H. M.(2012): Response of some sunflower hybrids to different levels of plant density. - APCBEE Procedia 4: 175-182.

[24] IPCC (Intergovernmental Panel on Climate Change) (2013): Drought in a Changing Climate: AR5 and Recent Scientific Advances. - IPCC, Geneva.

[25] Iqbal, N., Ashraf, M. Y., Ashraf, M. (2005): Influence of water stress and exogenous glycinebetaine on sunflower achene weight and oil percentage. - International Journal of Environmental Science \& Technology 2(2): 155-160.

[26] Kakar, A. A., Soomro, A. G. (2001): Effect of water stress on the growth, yield and oil content of sunflower. - Pak. J. Agri. Sei. 38: 1-2.

[27] Kang, S., Shi, W., Zhang, J. (2000): An improved water-use efficiency for maize grown under regulated deficit irrigation. - Field Crops Research 67(3): 207-214.

[28] Karim, T. H., Karim, K. (2001): Water demand of crops at Smaquly Watershed/ Koya. FAO Representation in Iraq. FAO Coordination Office for Northern Iraq, Erbil, Iraq.

[29] Kassab, O. M., Abo Ellil, A. A., Abo El-Kheir, M. S. (2012): Water use efficiency and productivity of two sunflower cultivars as influenced by three rates of drip irrigation water. - Journal of Applied Sciences Research 8(7): 3524-3529.

[30] Kazemeini, S. A., Edalat, M., Shekoofa, A. (2009): Interaction effects of deficit irrigation and row spacing on sunflower (Helianthus annuus L.) growth, seed yield, and oil yield. African Journal of Agricultural Research 4(11): 1165-1170.

[31] Kirda, C., Topcu, S., Çetın, M., Kaman, H., Topaloğlu, F., Derıcı, M. R., Daşgan, Y. (2006): Partial Root Drying and Conventional Deficit Irrigation for Increasing IrrigationWater Use Efficiency of Major Crops in the Mediterranean Region. - 18th International Soil Meeting (ISM) on "Soils Sustaining Life on Earth, Managing Soil and Technology" Proceedings 1: 272-278.

[32] Kurdistan Regional Government (2018): Kurdistan's geography and climate. http://cabinet.gov.krd/a/d.aspx?s=010000\&l=12\&a=18656.

[33] Langeroodi, A. R. S., Kamkar, B., da Silva, J. A. T., Ataei, M. (2014): Response of sunflower cultivars to deficit irrigation. - Helia 37(60): 37-58. 
[34] Lorenz, O. A., Maynard, D. N. (1980): Knott's Handbook for Vegetable Growers. - John Wiley \& Sons, New York.

[35] Mahender, S., Harbir, S., Tej, S., Jhorar, R. K., Singh, B. P. (2000): Seed yield, water use and water-use efficiency of sunflower (Helianthus annuus) genotypes under irrigation and nitrogen variables. - Indian Journal of Agronomy 45(1): 188-192.

[36] Martyniak, L. (2008): Response of spring cereals to a deficit of atmospheric precipitation in the particular stages of plant growth and development. - Agricultural Water Management 95(3): 171-178.

[37] Michael, A. (1978): Irrigation and Theory Practice. - Vikas Pub. House PVT LTD, New Delhi.

[38] Mila, A. J., Ali, M. H. (2016): Irrigation yield response factor of mustard at different growth phases. - International Journal of Experimental Agriculture 6(1): 15-21.

[39] Moutonnet, P. (2002): Yield response factors of field crops to deficit irrigation. - Deficit Irrigation Practices. Water Reports 22, FAO, Rome, pp. 11-15.

[40] Rauf, S., Jamil, N., Tariq, S. A., Khan, M., Kausar, M., Kaya, Y. (2017): Progress in modification of sunflower oil to expand its industrial value. - Journal of the Science of Food and Agriculture 97(7): 1997-2006.

[41] Reddy, G. K. M., Dangi, K. S., Kumar, S. S., Reddy, A. V. (2003): Effect of moisture stress on seed yield and quality in sunflower. - Journal of Oilseeds Research 20: 282-283.

[42] Sezen, S. M., Yazar, A., Kapur, B., Tekin, S. (2011): Comparison of drip and sprinkler irrigation strategies on sunflower seed and oil yield and quality under Mediterranean climatic conditions. - Agricultural Water Management 98(7): 1153-1161.

[43] Shafi, M., Bakht, J., Mohammad, Y., Aman, K. (2013): Effects of irrigation regime on growth and seed yield of sunflower (Helianthus annuus L.). - Pak. J. Bot. 45(6): 19952000.

[44] Silva, A. R. A., Bezerra, F. M. L., de Freitas, C. A. S., Amorim, A. V., de Carvalho, L. C. C., Pereira Filho, J. V. (2014): Coeficientes de sensibilidade ao déficit hídrico para a cultura do girassol nas condições do semiárido cearense. - Revista Brasileira De Agricultura Irrigada-RBAI 8(1): 38-51.

[45] Sinaki, J. M., Heravan, E. M., Rad, A. H. S., Noor Mohammadi Gand, G., Zarei, G. (2007): The effects of water deficit during growth stages of oilseed rape (Brassica napus L). - American-Eurasian Journal of Agricultural and Environmental Sciences 2: 417-422.

[46] Steduto, P., Hsiao, T. C., Fereres, E., Raes, D. (2012): Crop Yield Response to Water. Vol. 1028. - FAO, Rome.

[47] Sullu, A., Dagdelen, N. (2015): The evaluation of drip irrigation on second crop sunflower yield and quality in Soke region. - Journal of Adnan Menderes University Agricultural Faculty 12(1): 45-54.

[48] Sun, H. Y., Liu, C. M., Zhang, X. Y., Shen, Y. J., Zhang, Y. Q. (2006): Effects of irrigation on water balance, yield and WUE of winter wheat in the North China Plain. Agricultural Water Management 85(1-2): 211-218.

[49] Thomas, G. W. (1996): Soil pH and Soil Acidity. Methods of Soil Analysis. Part 3. Chemical Methods. - ASA, Madison, WI, pp. 475-490.

[50] Tian, F. P., Zhang, Z. N., Chang, X. F., Sun, L., Wie, X. H., Wu, G. L. (2016): Effects of biotic and abiotic factors on soil organic carbon in a semi-arid grassland. - Journal of Soil Science and Plant Nutrition 16(4): 1087-1096.

[51] Tolga, E., Lokman, D. (2003): Yield response of sunflower to water stress under Tekirdag conditions. - Helia 26(38): 149-158.

[52] Turner, N. C. (2004): Agronomic options for improving rainfall-use efficiency of crops in dryland farming systems. - Journal of Experimental Botany 55(407): 2413-2425.

[53] Viscardi, S., Ventorino, V., Duran, P., Maggio, A., De Pascale, S., Mora, M. L., Pepe, O. (2016): Assessment of plant growth promoting activities and abiotic stress tolerance of Azotobacter chroococcum strains for potential use in sustainable agriculture. - Journal of Soil Science and Plant Nutrition 16(3): 848-863. 
[54] WWP (2017): The United Nations World Water Development Report 2017. Wastewater: The Untapped Resource. - WWP, Jacksonville, FL.

[55] XLSTAT (2017): Data Analysis and Statistical Solution for Microsoft Excel. Addinsoft, Paris, France.

\section{APPENDIX}

Mean squares of variance analysis for seed yield, IWUE, and WUE at both locations

\begin{tabular}{|c|c|c|c|c|}
\hline S.O.V & d.f & $\begin{array}{l}\text { Seed yield } \\
\mathrm{kg} \mathrm{ha}^{-1}\end{array}$ & $\begin{array}{c}\text { Irrigation water use } \\
\text { efficiency } \\
\left(\mathrm{kg} \mathrm{ha}^{-1} \mathbf{m m}^{-1}\right)\end{array}$ & $\begin{array}{c}\begin{array}{c}\text { Water use } \\
\text { efficiency } \\
\left(\mathrm{kg} \mathrm{ha}^{-1} \mathbf{~ m m}^{-1}\right)\end{array}\end{array}$ \\
\hline \multicolumn{5}{|c|}{ Kanipanka Location } \\
\hline Block & 2 & 19239.73 & 0.036 & 0.073 \\
\hline Irrigation & 3 & $1351140 * *$ & $4.671 * *$ & $9.531 * *$ \\
\hline E (a) & 6 & 23042.79 & 0.053 & 0.108 \\
\hline Genotype & 2 & $4538945 * *$ & $11.257 * *$ & $22.973 * *$ \\
\hline Irrigation $_{\mathrm{x}}$ Genotype & 6 & $59495.04 * *$ & $0.199 * *$ & $0.406 * *$ \\
\hline $\mathrm{E}(\mathrm{b})$ & 16 & 18852.97 & 0.043 & 0.088 \\
\hline \multicolumn{5}{|c|}{ Qlyasan Location } \\
\hline Block & 2 & 36831.84 & 0.134 & 0.318 \\
\hline Irrigation & 3 & $1309368 * *$ & $9.854 * *$ & $23.323 * *$ \\
\hline $\mathrm{E}(\mathrm{a})$ & 6 & 111937.5 & 0.352 & 0.833 \\
\hline Genotype & 2 & $11904062 * *$ & $29.743 * *$ & $70.399 * *$ \\
\hline Irrigation ${ }_{\mathrm{x}}$ Genotype & 6 & $265607.9^{* *}$ & $0.729 * *$ & $1.724^{*}$ \\
\hline $\mathrm{E}(\mathrm{b})$ & 16 & 84077.5 & 0.198 & 0.468 \\
\hline
\end{tabular}

*Significant at $0.05, * *$ significant at 0.01 